\title{
Effects of Gatifloxacin on Serum Glucose Concentration in Normal and Diabetic Rats
}

\author{
Yasuyoshi Ishiwata, Yasuaki SAnAda, and Masato YasuHarA* \\ Department of Hospital Pharmacy, School of Medicine, Tokyo Medical and Dental University; 1-5-45 Yushima, \\ Bunkyo-ku, Tokyo 113-8519, Japan. Received October 28, 2005; accepted December 5, 2005
}

\begin{abstract}
To clarify the mechanisms of gatifloxacin (GFLX)-induced hypoglycemia and hyperglycemia, the effect of GFLX on serum glucose levels was investigated in normal and diabetic rats. Rats received an intravenous injection of GFLX and their arterial blood was sampled periodically. Diabetic rats were produced by the intraperitoneal injection of streptozotocin and nicotinamide. In normal rats, the serum glucose concentration was decreased by GFLX at 25 and $50 \mathrm{mg} / \mathrm{kg}$, while it was elevated $0.25 \mathrm{~h}$ after the injection of $100 \mathrm{mg} / \mathrm{kg} \mathrm{of} \mathrm{GFLX.}$ Serum immunoreactive insulin (IRI) levels increased as the dose of GFLX increased. The serum epinephrine concentration rose rapidly after the injection of GFLX at 50 and $100 \mathrm{mg} / \mathrm{kg}$. In diabetic rats, the serum glucose concentration was actually increased by GFLX at $50 \mathrm{mg} / \mathrm{kg}$. The baseline concentration of IRI was lower and the degree of the elevation caused by GFLX was smaller in diabetic rats. Both diabetic and control rats showed an increase in the serum epinephrine concentration after the injection of $50 \mathrm{mg} / \mathrm{kg}$ of GFLX. In conclusion, GFLXinduced secretion of insulin and epinephrine would contribute to the abnormalities in glucose homeostasis. The response of serum glucose to GFLX may differ between diabetic and normal rats due to the alteration of insulin secretion.
\end{abstract}

Key words gatifloxacin; hypoglycemia; hyperglycemia; insulin; epinephrine; diabetes mellitus

Gatifloxacin (GFLX), a novel fluoroquinolone, has a broad spectrum of activity against gram-positive, gram-negative, and anaerobic bacteria, ${ }^{1,2)}$ and has been used for the treatment of various infectious diseases. ${ }^{3)}$ However, clinical cases involving abnormalities in the regulation of blood glucose concentrations after oral or intravenous administration of GFLX have been reported; some cases were caused hyperglycemia $^{4-7)}$ and others, hypoglycemia. ${ }^{5-9)}$ In many cases, these adverse events were observed in patients with diabetes mellitus, ${ }^{10)}$ thus diabetes mellitus was considered as one of the risk factors for GFLX-induced hyperglycemia and hypoglycemia. In Japan, an Emergency Safety Information statement was issued in March 2003, and the contraindication of GFLX in patients with diabetes mellitus was added to the package insert. ${ }^{11,12)}$

Cases of hypoglycemia induced by other fluoroquinolones such as enoxacin, ${ }^{13)}$ lomefloxacin, ${ }^{14)}$ and norfloxacin ${ }^{15)}$ were reported previously. In a case of enoxacin-induced hypoglycemia, the serum level of immunoreactive insulin (IRI) was found to have increased during the hypoglycemic episode. ${ }^{13)}$ Maeda et $a l .{ }^{16)}$ reported that some fluoroquinolones including lomefloxacin can promote the release of insulin from rat pancreatic islets, and Saraya et al. ${ }^{17)}$ reported that GFLX and temafloxacin stimulated the secretion of insulin by inhibiting ATP-sensitive $\mathrm{K}^{+}$channels of pancreatic $\beta$-cells. Therefore, it is thought that fluoroquinolone-induced hypoglycemia can be caused by an increase in insulin release. On the other hand, the mechanism of hyperglycemia induced by GFLX is not well understood.

In the present study, we investigated the effect of GFLX on serum glucose concentrations in normal and diabetic rats in order to clarify the mechanisms of GFLX-induced abnormalities during glucose homeostasis.

\section{MATERIALS AND METHODS}

Animals Male Wistar rats (Japan SLC, Hamamatsu,
Japan) weighing $240-270 \mathrm{~g}$ were used. The rats were housed in controlled environment and fasted overnight before the experiment. They had indwelling cannulas implanted in the left carotid artery and jugular vein under light ether anesthesia for blood sampling and intravenous injection, respectively, and were fasted during the experiment. The animal experiments were performed in accordance with The Guidelines for Animal Experiments of Tokyo Medical and Dental University.

Materials GFLX hydrate was obtained from Kyorin Pharmaceutical Co., Ltd. (Tokyo, Japan). GFLX was dissolved in $1 \mathrm{~mol} / \mathrm{l}$ sodium hydroxide and the solution was adjusted to $\mathrm{pH} 7$ with $1 \mathrm{~mol} / \mathrm{l}$ hydrochloric acid. Sparfloxacin as an internal standard was obtained from Dainippon Pharmaceutical Co., Ltd. (Osaka, Japan). Streptozotocin was purchased from Wako Pure Chemical Industries (Osaka, Japan), and nicotinamide was purchased from Nacalai Tesque Inc. (Kyoto, Japan). Streptozotocin was dissolved in $0.05 \mathrm{~mol} / 1$ citrate buffer $(\mathrm{pH} 4.5)$ and nicotinamide was dissolved in normal saline. All other chemicals were of analytical grade.

Effects of GFLX on Serum Concentrations of Glucose, IRI, and Epinephrine in Normal Rats The rats received an intravenous injection of GFLX at a dose of 25, 50, or $100 \mathrm{mg} / \mathrm{kg}$ through the cannula. Blood samples were obtained at $0,0.25,0.5,0.75,1,2$, and $4 \mathrm{~h}$ to determine serum concentrations of glucose, IRI, and GFLX. An equivalent volume of normal saline was injected into the control rats.

In another set of rats, GFLX at a dose of 50 or $100 \mathrm{mg} / \mathrm{kg}$ was injected, and blood samples were obtained at $0,0.25,1$, and $4 \mathrm{~h}$ to determine serum epinephrine concentration. An equivalent volume of normal saline was injected into the control rats.

For the pharmacokinetic analysis of GFLX, the third set of rats received an intravenous injection of GFLX at 25,50 , or $100 \mathrm{mg} / \mathrm{kg}$, and blood samples were obtained at $0.25,0.5,1$, $2,4,6$, and $8 \mathrm{~h}$ to determine serum GFLX concentration.

Effects of GFLX on Serum Concentrations of Glucose, 
IRI, and Epinephrine in Diabetic Rats To induce diabetes mellitus in rats, streptozotocin $(65 \mathrm{mg} / \mathrm{kg})$ was injected intraperitoneally into overnight-fasted rats $15 \mathrm{~min}$ after an intraperitoneal injection of nicotinamide $(110 \mathrm{mg} / \mathrm{kg}){ }^{18,19)}$ Seven days later, rats with an overnight-fasted serum glucose level above $160 \mathrm{mg} / \mathrm{dl}$ were taken for the experiment. The equivalent volume of $0.05 \mathrm{~mol} / 1$ citrate buffer (vehicle) and nicotinamide were injected as a control (non-diabetic rats).

GFLX was injected through the cannula into diabetic and non-diabetic rats at $50 \mathrm{mg} / \mathrm{kg}$, and the equivalent volume of normal saline was injected into other diabetic rats (diabetic control rats). Blood samples were obtained at $0,0.25,0.5,1$, $2,4,6$, and $8 \mathrm{~h}$ to determine serum concentrations of glucose and GFLX. Serum IRI concentration was determined at 0 , $0.5,1,2,4$, and $6 \mathrm{~h}$.

In another set of rats, same procedure was performed, and blood samples were obtained at $0,0.25,1$, and $4 \mathrm{~h}$ to determine serum epinephrine concentration.

Analytical Methods The serum concentration of glucose was determined by the glucose oxidase method using a Glucose CII-test Wako (Wako Pure Chemical Industries). The serum concentration of IRI was determined by enzyme immunoassay using a Glazyme Insulin-EIA TEST (Wako Pure Chemical Industries).

The serum concentration of epinephrine was determined by HPLC with pre-column fluorescence derivatization, using a slightly modified method of Mitsui et al. ${ }^{20)}$ Briefly, $400 \mu \mathrm{l}$ of serum was mixed with $200 \mu \mathrm{l}$ of $2.0 \mathrm{~mol} / 1$ perchloric acid and $20 \mu \mathrm{l}$ of internal standard solution $(2 \mu \mathrm{mol} / 1$ isoproterenol), and centrifuged at $3000 \boldsymbol{g}$ for $10 \mathrm{~min}$. The supernatant $(400 \mu \mathrm{l})$ was neutralized with $1.0 \mathrm{~mol} / \mathrm{l}$ of potassium carbonate to $\mathrm{pH} 6-7$, and centrifuged at $3000 \boldsymbol{g}$ for $10 \mathrm{~min}$. The supernatant $(450 \mu \mathrm{l})$ was added with $4.5 \mathrm{ml}$ of chloroform to extract GFLX, and was shaken for $5 \mathrm{~min}$. The aqueous layer $(90 \mu \mathrm{l})$ was mixed with $6 \mu \mathrm{l}$ of $20 \mathrm{mmol} / \mathrm{l}$ potassium ferricyanide, $90 \mu \mathrm{l}$ of acetonitrile, and $30 \mu \mathrm{l}$ of $0.1 \mathrm{~mol} / 1$ 1,2-diphenylethylenediamine solution; then the mixture was allowed to stand at $37^{\circ} \mathrm{C}$ for $40 \mathrm{~min}$. The reaction was stopped by cooling the mixture in ice-water, and $100 \mu \mathrm{l}$ was injected into the HPLC system. The mobile phase was $50 \mathrm{mmol} / 1$ Tris-hydrochloride buffer ( $\mathrm{pH}$ 7.0)-methanolacetonitrile $(40: 20: 40, \mathrm{v} / \mathrm{v} / \mathrm{v})$. Epinephrine and the internal standard were detected with a fluorescence detector: excitation and emission wavelengths were set at 345 and $485 \mathrm{~nm}$, respectively.

The serum concentration of GFLX was determined by the HPLC method. Fifty microliters of serum and $50 \mu \mathrm{l}$ of acetonitrile containing internal standard were mixed and vortexed for $10 \mathrm{~s}$. After a centrifugation $(13000 \boldsymbol{g}, 2 \mathrm{~min}), 70 \mu \mathrm{l}$ of supernatant was added to $70 \mu \mathrm{l}$ of $1 \%$ triethylamine adjusted to $\mathrm{pH} 2.5$ with phosphoric acid. The mixture was vortexed for $10 \mathrm{~s}$, and $40 \mu \mathrm{l}$ was injected into the HPLC system. The mobile phase was $1 \%$ triethylamine adjusted to $\mathrm{pH} 2.5$ with phosphoric acid-acetonitrile $(84: 16$, v/v). GFLX and the internal standard were detected with an ultraviolet detector set at a wavelength of $290 \mathrm{~nm}$.

The HPLC apparatus was a LC-10A (Shimadzu Co., Kyoto, Japan) equipped with an ultraviolet spectrometer (SPD-6A, Shimadzu Co.) and a spectrofluorimeter (RF550A, Shimadzu Co.). The column was TSK-gel ODS-80TM ( $5 \mu \mathrm{m}, 4.6 \mathrm{~mm}$ i.d. $\times 15 \mathrm{~cm}$, TOSOH, Japan) and was kept at room temperature. The flow rate was $1.0 \mathrm{ml} / \mathrm{min}$.

Statistical Methods All data represent the mean \pm S.E. Differences in the means between two groups were evaluated using Student's $t$ test. Other statistical evaluations were performed using Tukey-Kramer's multiple comparison test. Differences were considered significant at $p<0.05$.

\section{RESULTS}

Effects of GFLX on Serum Concentrations of Glucose, IRI, and Epinephrine in Normal Rats The changes in the serum glucose concentration after the injection of GFLX are shown in Fig. 1. The concentration was $129 \pm 2 \mathrm{mg} / \mathrm{dl}$ at baseline. With the injection of 25 and $50 \mathrm{mg} / \mathrm{kg}$ of GFLX, it decreased at $1-2 \mathrm{~h}$ and recovered at $4 \mathrm{~h}$. In contrast, a rapid elevation of the serum glucose concentration was observed after the injection of $100 \mathrm{mg} / \mathrm{kg}$ of GFLX. The concentration increased to $216 \pm 16 \mathrm{mg} / \mathrm{dl}$ at $0.25 \mathrm{~h}$ and recovered at $2 \mathrm{~h}$.

The changes in the serum IRI concentration after the injection of GFLX are shown in Fig. 2. The concentration was $8.3 \pm 0.5 \mu \mathrm{U} / \mathrm{ml}$ at baseline, and rose to $15.8 \pm 1.7$ and $19.7 \pm 2.7 \mu \mathrm{U} / \mathrm{ml} 1 \mathrm{~h}$ after the injection of 50 and $100 \mathrm{mg} / \mathrm{kg}$ of GFLX, respectively. In addition, the serum IRI concentration tended to increase at a dose of $25 \mathrm{mg} / \mathrm{kg}$, though the rise was not statistically significant.

The changes in the serum epinephrine concentration after the injection of GFLX are shown in Fig. 3. The concentration was $0.46 \pm 0.05 \mathrm{ng} / \mathrm{ml}$ at baseline, and was observed dose-related increase to be $1.07 \pm 0.10$ and $4.98 \pm 1.06 \mathrm{ng} / \mathrm{ml}$ at

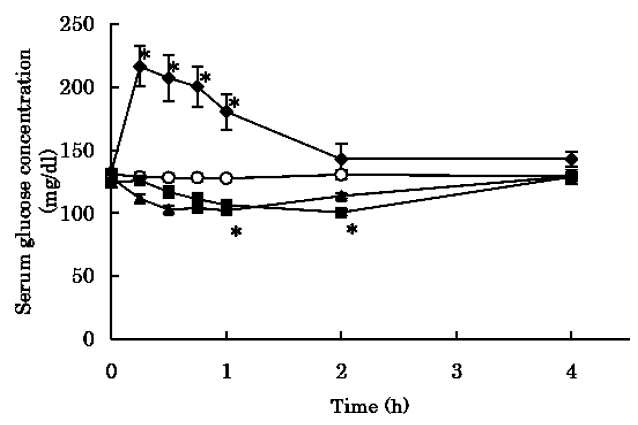

Fig. 1. Serum Glucose Concentrations after an Intravenous Injection of Saline ( $\bigcirc$, Control, $n=8)$, GFLX $25 \mathrm{mg} / \mathrm{kg}(\boldsymbol{\Lambda}, n=8)$, GFLX $50 \mathrm{mg} / \mathrm{kg}(\boldsymbol{\square}$, $n=8)$, or GFLX $100 \mathrm{mg} / \mathrm{kg}(\bullet, n=6)$ in Normal Rats

Vertical bars show the mean \pm S.E. $* p<0.05$ compared with the control group.

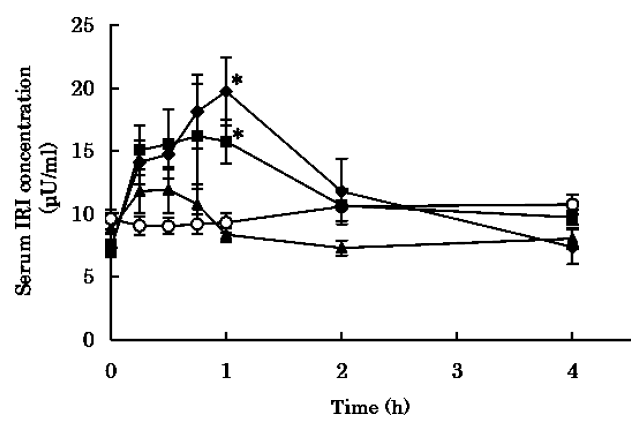

Fig. 2. Serum IRI Concentrations after an Intravenous Injection of Saline (○, Control, $n=8)$, GFLX $25 \mathrm{mg} / \mathrm{kg}(\boldsymbol{\Lambda}, n=8)$, GFLX $50 \mathrm{mg} / \mathrm{kg}(\boldsymbol{\square}, n=8)$, or GFLX $100 \mathrm{mg} / \mathrm{kg}(\bullet, n=6)$ in Normal Rats

Vertical bars show the mean \pm S.E. $* p<0.05$ compared with the control group. 


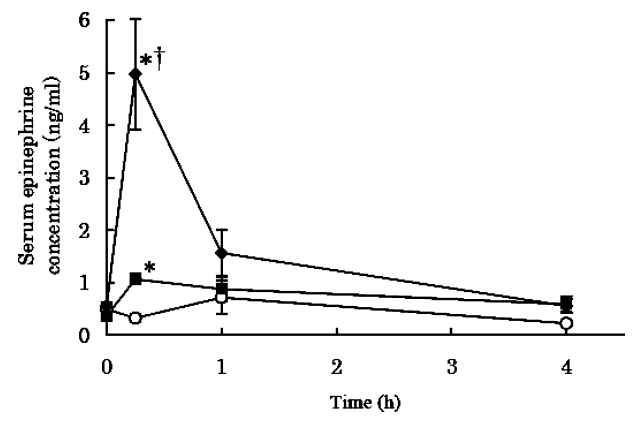

Fig. 3. Serum Epinephrine Concentrations after an Intravenous Injection of Saline $(\bigcirc$, Control, $n=8)$, GFLX $50 \mathrm{mg} / \mathrm{kg}(\mathbf{\square}, n=9)$, or GFLX $100 \mathrm{mg} / \mathrm{kg}(\bullet, n=7)$ in Normal Rats

Vertical bars show the mean \pm S.E. $* p<0.05$ compared with the control group. $\dagger p<0.05$ compared with that at $50 \mathrm{mg} / \mathrm{kg}$.

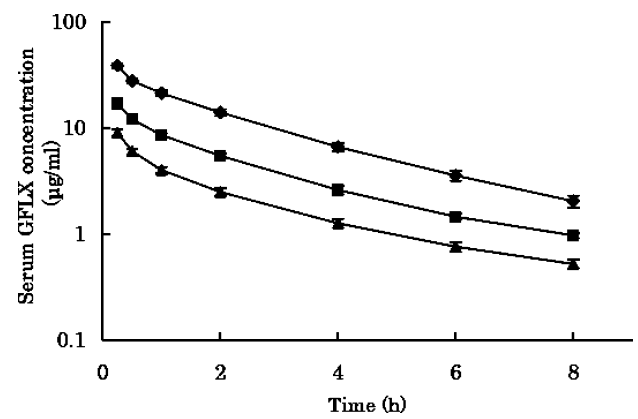

Fig. 4. Serum Concentration-Time Profiles of GFLX after an Intravenous Injection in Normal Rats

GFLX at a dose of $25 \mathrm{mg} / \mathrm{kg}(\boldsymbol{\Lambda}, n=11), 50 \mathrm{mg} / \mathrm{kg}(\boldsymbol{\square}, n=11)$, or $100 \mathrm{mg} / \mathrm{kg}($ $n=7$ ) was injected intravenously into normal rats. Vertical bars show the mean \pm S.E.

Table 1. Pharmacokinetic Parameters of GFLX after Intravenous Injection to Normal Rats

\begin{tabular}{lccc}
\hline \hline & \multicolumn{3}{c}{ Dose of GFLX (mg/kg) } \\
\cline { 2 - 4 } & 25 & 50 & 100 \\
\hline Number of animals & 11 & 11 & 7 \\
$C L_{\text {tot }}(1 / \mathrm{h} / \mathrm{kg})$ & $1.45 \pm 0.11$ & $1.40 \pm 0.07$ & $1.15 \pm 0.09$ \\
$V_{\mathrm{c}}(1 / \mathrm{kg})$ & $1.83 \pm 0.18$ & $1.93 \pm 0.14$ & $1.41 \pm 0.12$ \\
$k_{12}\left(\mathrm{~h}^{-1}\right)$ & $1.41 \pm 0.19$ & $1.42 \pm 0.30$ & $2.42 \pm 0.33$ \\
$k_{21}\left(\mathrm{~h}^{-1}\right)$ & $1.13 \pm 0.10$ & $1.44 \pm 0.17$ & $2.27 \pm 0.16$
\end{tabular}

Pharmacokinetic parameters were analyzed with a two-compartment model. Data represent the mean \pm S.E. $C L_{\text {tot }}$; total body clearance, $V_{c}$; distribution volume in the central compartment. $k_{12}$ and $k_{21}$; rate constants for drug moving from compartment 1 to compartment 2 and vice versa.

$0.25 \mathrm{~h}$ after an injection of 50 and $100 \mathrm{mg} / \mathrm{kg}$ GFLX, respectively.

Time profiles of serum GFLX concentrations after an intravenous injection are shown in Fig. 4. Pharmacokinetic parameters of GFLX were analyzed using a two-compartment model and no significant difference was found among the three groups, as shown in Table 1.

Effects of GFLX on Serum Concentrations of Glucose, IRI, and Epinephrine in Diabetic Rats The changes in the serum glucose concentration after the injection of GFLX in diabetic rats are shown in Fig. 5. The concentration at baseline was $293 \pm 21,310 \pm 25$, and $134 \pm 3 \mathrm{mg} / \mathrm{dl}$ in diabetic GFLX-treated, diabetic control, and non-diabetic GFLXtreated rats, respectively. In contrast to normal rats, diabetic

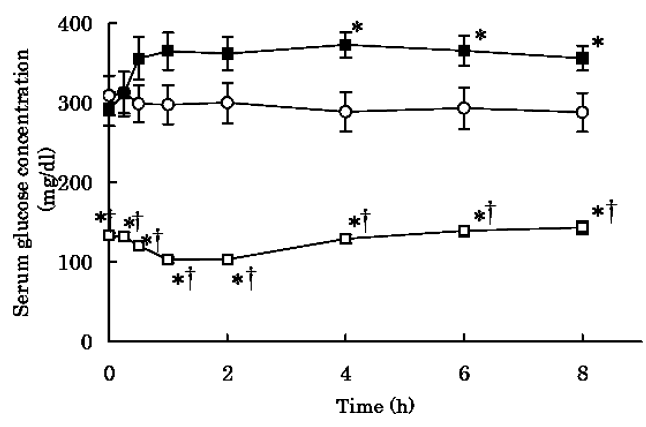

Fig. 5. Effect of GFLX on Serum Glucose Concentrations in Diabetic Rats: Diabetic Control $(\bigcirc, n=10)$; Diabetic GFLX-Treated ( $\boldsymbol{Q}, n=13)$; Non-diabetic GFLX-Treated $(\square, n=10)$

GFLX was injected intravenously at $50 \mathrm{mg} / \mathrm{kg}$. Vertical bars show the mean \pm S.E. $* p<0.05$ compared with diabetic control rats. $\uparrow p<0.05$ compared with diabetic GFLXtreated rats.

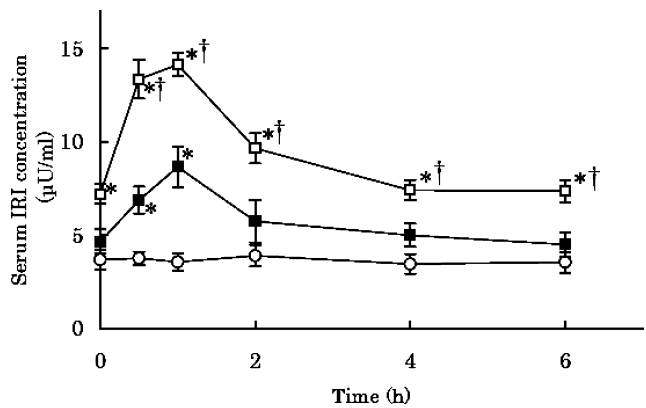

Fig. 6. Effect of GFLX on Serum IRI Concentrations in Diabetic Rats: Diabetic Control ( $\bigcirc, n=10)$; Diabetic GFLX-Treated $(\boldsymbol{\square}, n=13)$; Non-diabetic GFLX-Treated $(\square, n=10)$

GFLX was injected intravenously at $50 \mathrm{mg} / \mathrm{kg}$. Vertical bars show the mean \pm S.E. $* p<0.05$ compared with diabetic control rats. ${ }^{\dagger} p<0.05$ compared with diabetic GFLXtreated rats.

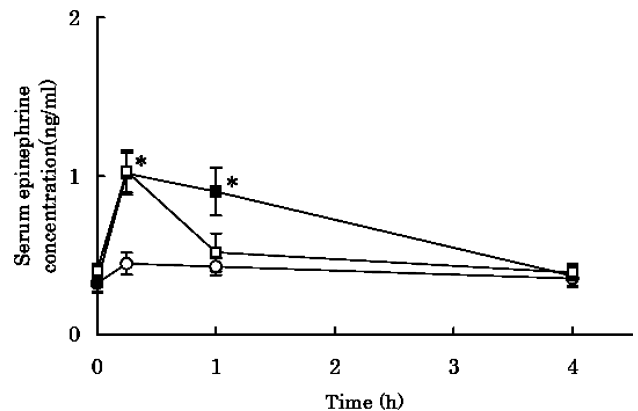

Fig. 7. Effect of GFLX on Serum Epinephrine Concentrations in Diabetic Rats: Diabetic Control $(O, n=8)$; Diabetic GFLX-Treated $(\boldsymbol{\square}, n=8)$; Nondiabetic GFLX-Teated $(\square, n=7)$

GFLX was injected intravenously at $50 \mathrm{mg} / \mathrm{kg}$. Vertical bars show the mean \pm S.E. $* p<0.05$ compared with diabetic control rats.

rats had elevated serum glucose levels after an injection of $50 \mathrm{mg} / \mathrm{kg}$ GFLX.

The changes in the serum IRI concentration are shown in Fig. 6. The concentration at baseline was 4.78 \pm 0.70 , $3.71 \pm 0.63$, and $7.71 \pm 0.04 \mu \mathrm{U} / \mathrm{ml}$ in diabetic GFLX-treated, diabetic control, and non-diabetic GFLX-treated rats, respectively. Serum IRI concentrations were raised by the administration of GFLX both in diabetic and in non-diabetic rats; however, the change was less extensive in the diabetic than non-diabetic rats.

The changes in the serum epinephrine concentration are shown in Fig. 7. The concentration increased at $0.25 \mathrm{~h}$ after 


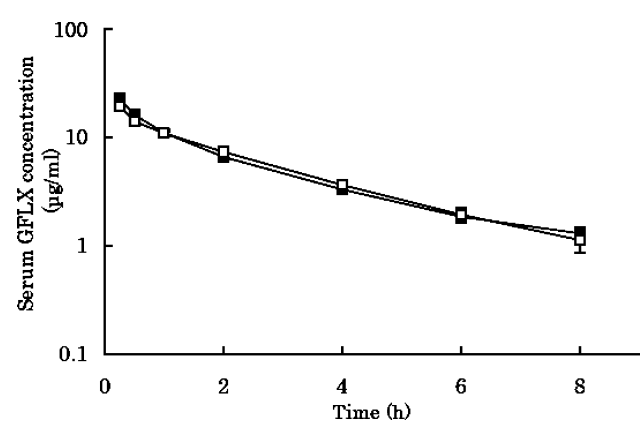

Fig. 8. Serum Concentration-Time profiles of GFLX after an Intravenous Injection in Diabetic Rats

GFLX at $50 \mathrm{mg} / \mathrm{kg}$ was injected intravenously into diabetic $(\boldsymbol{\square}, n=13)$ and non-diabetic $(\square, n=10)$ rats. Vertical bars show the mean \pm S.E.

Table 2. Pharmacokinetic Parameters of GFLX after Intravenous Injection to Diabetic and Non-diabetic Rats

\begin{tabular}{lcc}
\hline \hline & Diabetic rats & Control \\
\hline Number of animals & 13 & 10 \\
$C L_{\text {tot }}(1 / \mathrm{h} / \mathrm{kg})$ & $1.09 \pm 0.10$ & $1.04 \pm 0.10$ \\
$V_{\mathrm{c}}(1 / \mathrm{kg})$ & $1.64 \pm 0.13$ & $1.47 \pm 0.14$ \\
$k_{12}\left(\mathrm{~h}^{-1}\right)$ & $0.91 \pm 0.08$ & $1.11 \pm 0.29$ \\
$k_{21}\left(\mathrm{~h}^{-1}\right)$ & $0.99 \pm 0.07$ & $1.38 \pm 0.28$
\end{tabular}

Pharmacokinetic parameters were analyzed with a two-compartment model. Data represent the mean \pm S.E. $C L_{\text {tot }}$; total body clearance, $V_{\mathrm{c}}$; distribution volume in the central compartment. $k_{12}$ and $k_{21}$; rate constants for drug moving from compartment 1 to compartment 2 and vice versa.

an injection of $50 \mathrm{mg} / \mathrm{kg}$ GFLX in both diabetic and non-diabetic rats.

Time profiles of serum GFLX concentrations after the injection of $50 \mathrm{mg} / \mathrm{kg}$ of GFLX in diabetic and non-diabetic rats are shown in Fig. 8. As shown in Table 2, the pharmacokinetic parameters of GFLX after an intravenous injection were not affected by the induction of diabetes mellitus.

\section{DISCUSSION}

To clarify the mechanisms of GFLX-induced hyperglycemia and hypoglycemia in humans, we investigated the effect of GFLX on serum glucose concentrations in fasted rats. After an intravenous injection of GFLX into normal fasted rats at three different doses, a temporal change in the serum glucose level was observed, depending on the dose of GFLX: the level was decreased at 25 and $50 \mathrm{mg} / \mathrm{kg}$ and increased at $100 \mathrm{mg} / \mathrm{kg}$. These results suggest that hypoglycemia and hyperglycemia can be induced by a single dose of GFLX in rats, and that the rats may be an appropriate model with which to determine the mechanism of GFLX-induced abnormalities in glucose regulation.

This study showed that GFLX can stimulate the secretion of epinephrine. Many endogenous compounds are recognized as factors regulating the serum concentration of glucose, including catecholamines, glucagon, and glucocorticoids. ${ }^{21)}$ Epinephrine activates glycogenolysis and glyconeogenesis to elevate serum glucose levels, ${ }^{22}$ and, its effect is relatively rapid. ${ }^{23)}$ In the present study, serum epinephrine concentrations were elevated immediately after the administration of GFLX (Fig. 3). This result suggests that the rapid rise in the serum glucose concentration is associated with the GFLX-in- duced secretion of epinephrine. Also, in this study, serum epinephrine concentrations were elevated to $1.07 \pm 0.10$ and $4.98 \pm 1.06 \mathrm{ng} / \mathrm{ml}$ at $0.25 \mathrm{~h}$ after an injection of GFLX at 50 and $100 \mathrm{mg} / \mathrm{kg}$, respectively. Several drugs including neostigmine $^{24)}$ and theophylline ${ }^{25)}$ have been reported to stimulate the release of epinephrine, contributing to a hyperglycemic tendency. Iguchi et al. ${ }^{24)}$ reported that the intracerebroventricular injection of neostigmine increased hepatic venous plasma epinephrine concentrations by $6.00 \pm 2.10 \mathrm{ng} / \mathrm{ml}$ at $30 \mathrm{~min}$ postadministration, though it was $0.43 \pm 0.12 \mathrm{ng} / \mathrm{ml}$ at preinjection, to affect the hepatic venous plasma glucose concentration. These reports suggest that, to raise the serum glucose level, a marked increase in the serum epinephrine concentration may be needed in normal rats.

Studies in vitro have found that several fluoroquinolones, including GFLX, inhibit ATP-sensitive $\mathrm{K}^{+}$channels of pancreatic $\beta$-cells to stimulate the secretion of insulin. ${ }^{16,17)} \mathrm{Gaj}$ jar et $a l .{ }^{26)}$ reported that, in patients with type 2 diabetes mellitus, GFLX caused an increase in serum insulin $1 \mathrm{~h}$ after its administration at a conventional dose, with a downward trend in the fasting glucose level. In the present study, an elevation of the serum IRI concentration was observed $1 \mathrm{~h}$ after the administration of GFLX at 50 or $100 \mathrm{mg} / \mathrm{kg}$ (Fig. 2). Since GFLX at $50 \mathrm{mg} / \mathrm{kg}$ promoted the insulin secretion without increasing serum glucose concentration, it is suggested that GFLX induces the secretion of insulin independent of epinephrine-induced hyperglycemia. Serum concentrations of GFLX $1 \mathrm{~h}$ after intravenous administration at 50 and $100 \mathrm{mg}$ $/ \mathrm{kg}$ were $8.57 \pm 0.38$ and $21.34 \pm 1.35 \mu \mathrm{g} / \mathrm{ml}$, respectively (Fig. 4). It was reported that the GFLX concentration in the pancreas $1 \mathrm{~h}$ after an intravenous injection was about six-fold that in serum. ${ }^{27}$ ) Therefore, expected GFLX concentrations in the pancreas at $1 \mathrm{~h}$ post-injection in this study were about 51 and $128 \mu \mathrm{g} / \mathrm{ml}$ at doses of 50 and $100 \mathrm{mg} / \mathrm{kg}$, respectively. On the other hand, Saraya et al. ${ }^{17)}$ reported that the secretion of insulin by pancreatic islets was stimulated in the presence of GFLX, $300 \mu \mathrm{mol} / 1$ (about $120 \mu \mathrm{g} / \mathrm{ml}$ ). These results suggest that the decreases in serum glucose levels at 25 and $50 \mathrm{mg} / \mathrm{kg}$ were associated with stimulated secretion of insulin, and confirm that GFLX-induced insulin secretion can produce hypoglycemia in an animal model.

As the second experiment, the effect of GFLX on the serum glucose concentration was investigated in diabetic rats. In contrast to normal rats, serum glucose levels tended to rise rapidly after the injection of GFLX at $50 \mathrm{mg} / \mathrm{kg}$ and reached a plateau at approximately $360 \mathrm{mg} / \mathrm{dl}$ in diabetic rats. This result suggests that the response of the serum glucose concentration to GFLX would be different between normal and diabetic rats.

The diabetic rats used in this study were produced using a combination of streptozotocin and nicotinamide. This model is characterized by a moderate and stable hyperglycemia and reduced pancreatic insulin stores. ${ }^{18)}$ In the present study, the serum IRI concentration was increased in diabetic rats at 0.5 and $1 \mathrm{~h}$, but less than that in non-diabetic rats (Fig. 6). In addition, the serum epinephrine concentration reached a maximal value at $0.25 \mathrm{~h}$ after the injection of GFLX at $50 \mathrm{mg} / \mathrm{kg}$ in both diabetic and non-diabetic rats, but the increased values did not differ significantly between the two groups. These findings indicate that the shortage of secreted insulin can affect serum glucose profiles in diabetic rats, resulting in 
an increase in the serum glucose concentration.

In this study, we examined the serum epinephrine concentration as a factor raising glucose levels. However, the profiles of the increase in serum glucose differed between diabetic and normal rats. In this regard, some drugs were reported to increase other factors affecting serum glucose concentrations. Rasekh et al. ${ }^{28)}$ reported that an acute intraperitoneal injection of selenium caused hyperglycemia, due to an increase in the plasma level of corticosterone, the main glucocorticoid in rats. Johansen et al. ${ }^{29)}$ reported that plasma insulin and glucagon levels were increased after an intravenous injection of morphine in fed rats, resulting in hyperglycemia. These factors may be concerned with GFLX-induced hyperglycemia in diabetes mellitus.

Clinically, in Japan, the oral dose of GFLX is 200 to $400 \mathrm{mg}$ per day, ${ }^{12)}$ and serum peak concentrations of GFLX are reported as 1.71 and $3.35 \mu \mathrm{g} / \mathrm{ml}$ at oral doses of 200 and $400 \mathrm{mg}$, respectively. ${ }^{30)}$ However, there has been a report that the serum GFLX concentration was $8.72 \mu \mathrm{g} / \mathrm{ml}$ after the oral administration of $400 \mathrm{mg}$ per day for $3 \mathrm{~d}$ in a patient with diabetic nephropathy, causing hypoglycemia followed by hyperglycemia. ${ }^{6)}$ This is approximately as high as the GFLX concentration in the present study at $25 \mathrm{mg} / \mathrm{kg}$, at which the serum glucose concentration is decreased in normal rats. Therefore, even at a conventional dose, clinicians should be aware of the potential for GFLX-induced hyperglycemia and hypoglycemia.

In conclusion, the GFLX-induced secretion of insulin and epinephrine would contribute to the abnormalities in glucose homeostasis. In diabetic rats, the response to GFLX of the serum glucose concentration would be different from that in normal rats due to the alteration of insulin secretion.

\section{REFERENCES}

1) Fukuda H., Oomori Y., Yamamoto T., Yasue T., Tomizawa H., Hori S., Hosaka M., Jpn. J. Chemother., 47 (Suppl. 2), 3-11 (1999).

2) Yamamoto T., Fukuda H., Niwata Y., Tomizawa H., Hosaka M., Oomori Y., Jpn. J. Chemother., 47 (Suppl. 2), 12-19 (1999).

3) Hosaka M., Folia Pharmacol. Jpn., 121, 447-456 (2003).

4) Happe M. R., Mulhall B. P., Maydonovitch C. L., Holtzmuller K. C., Ann. Intern. Med., 141, 968-969 (2004).

5) Biggs W. S., J. Am. Board. Fam. Pract., 16, 455- 457 (2003).

6) Yamauchi M., Nakayama K., Kitano T., Tsumaru S., Inashima M., Saiki Y., Hashimoto G., Wada Y., Yoshiga Y., Oda T., Shiomi K., Itoh
Y., Notsu K., Med. J. Shimane Prefectural Central Hosp., 28, 43-46 (2003).

7) Khovidhunkit W., Sunthornyothin S., Ann. Intern. Med., 141, 969 (2004).

8) Baker S. E., Hangii M. C., Ann. Pharmacother., 36, 1722-1726 (2002).

9) Brogan S. E., Cahalan M. K., Anesth. Analg., 101, 635-636 (2005).

10) Tamayama T., Tanaka Y., Saito A., Jpn. J. Chemother, 52, 521-529 (2004).

11) Emergency Safety Information statement about GFLX-induced hyperglycemia and hypoglycemia. 2003 March. Japan.

12) Package Insert. Gatiflo (gatifloxacin). Kyorin Pharmaceutical Co., Ltd., Tokyo, Japan. 2003 March.

13) Toyoda T., Muramatsu M., Ikeda H., Okamoto M., Isami Y., Ikuma T., Nakamura E., Fujii M., J. Jpn. Soc. Dial. Ther., 24, 1311-1314 (1991).

14) Suda M., Minami T., Aono H., Koh T., Hamada Y., Yashiro M., $J$. Kyoto City Hosp., 20, 41- 46 (2000).

15) Haruhara N., Niwa H., Kitayama S., Sakai N., J. Tomakomai City General Hosp., 14, 45-48 (2000).

16) Maeda N., Tamagawa T., Niki I., Miura H., Ozawa K., Watanabe G., Nonogaki K., Uemura K., Iguchi A., Br. J. Pharmacol., 117, 372-376 (1996).

17) Saraya A., Yokokura M., Gonoi T., Seino S., Eur. J. Pharmacol., 497, $111-117$ (2004).

18) Masiello P., Broca C., Gross R., Roye M., Manteghetti M., HillaireBuys D., Novelli M., Ribes G., Diabetes, 47, 224-229 (1998).

19) Shirwaikar A., Rajendran K., Kumar C. D., Bodla R., J. Ethnopharmacol., 91, 171-175 (2004).

20) Mitsui A., Nohta H., Ohkura Y., J. Chromatogr., 344, 61-70 (1985).

21) Shamoon H., Hendler R., Sherwin S., J. Clin. Endocrinol. Metab., 52, 1235-1241 (1981).

22) Cherrington A. D., Fuchs H., Stevenson R. W., Williams P. E., Alberti K. G. M. M., Steiner K. E., Am. J. Physiol., 247, E137-E144 (1984).

23) Issekutz B., Allen M., Metabolism, 21, 48-59 (1972).

24) Iguchi A., Yatomi A., Gotoh M., Matsunaga H., Uemura K., Miura H., Satake T., Tamagawa T., Sakamoto N., Brain Res., 507, 295-300 (1990).

25) Kearney T. E., Manoguerra A. S., Curtis G. P., Ziegler M. G., Ann. Intern. Med., 102, 766-769 (1985).

26) Gajjar D. A., LaCreta F. P., Kollia G. D., Stolz R. R., Berger S., Smith W. B., Swingle M., Grasela D. M., Pharmacotherapy, 20, 76S-86S (2000).

27) Idesawa A., Izawa S., Koseki N., Machida M., Toriumi C., Yuasa R., Komuro M., Nagatsu Y., Ishida R., Ohkubo H., Uchida H., Jpn. J. Chemother., 47 (Suppl. 2), 131-140 (1999).

28) Rasekh H. R., Potmis R. A., Nonavinakere V. K., Early J. L., Iszard M. B., Toxicol. Lett., 58, 199-207 (1991).

29) Johansen O., Jorde R., Tonnesen T., Burhol P. G., Tveita T., Reikeras O., Life Sci., 52, 141-146 (1993).

30) Nakashima M., Uematsu T., Kosuge K., Kusajima H., Ooie T., Ishida R., Uchida H., Jpn. J. Chemother., 47 (Suppl. 2), 175—207 (1999). 